\title{
Do Cryptocurrencies have a Future in Emerging Markets?Evidence from Mauritius
}

\author{
Eymen Errais ${ }^{1}$ Dana Luxmi Appavoo \\ LAREQUAD and Tunis Business School, University of Tunis \\ NS MANAGEMENT LTD, Mauritius and IAE Paris, Sorbonne Business School
}

\begin{abstract}
For the last two decades, we have witnessed major changes in technological advances. Most if not all individuals worldwide use technological tools to ease their lives. Mobile devices and computers are being used daily and through such devices, one can perform its investment or banking activities arround the clock. The purpose of this paper is to assess whether cryptocurrencies will have a future in emerging markets and especially in Mauritius. Mauritius is an island situated in the Indian Ocean and has a population of approximately one million two hundred citizens and ninety-one as at January 2019. The aim of the study is to investigate the factors that could lead to the adoption of cryptocurrencies in Mauritius. An online questionnaire was prepared and sent to 100 respondents and 71 were deemed as valid for the analysis. Our empirical findings showed that students and employed individuals could be the potential users of cryptocurrencies. Undoubtedly, the use of cryptocurrencies is strongly influenced by the regulations to be put in place. Recommendations have been made in view to assess the possible future of cryptocurrency in Mauritius.
\end{abstract}

Keywords: Blockchain, Cryptocurrency,Emerging Markets

JEL Classification : E22,E58, E71, G23, G28

\section{Introduction}

For the last two decades, Technology occupies a predominant place in the daily life of most individuals. The financial services sector has witnessed radical change along with technology. The introduction of blockchain technology and the development of cryptofinance are considered as key major changes.

According to (Harvey Campbell R. 2016, 2-7), cryptofinance refers to the efficient exchange of ownership, the verification of ownership, as well as the ability to algorithmically design conditional contracts, all with security, privacy and minimal trust without using centralized institutions. The cost involved while using the traditional methods for transactions is increasing and represent substantial amount. In simpler terms, according to (Chohan 2017, 1-9), a cryptocurrency can be referred to a digital asset which acts as a medium of exchange using the cryptography technology to secure the flows of transactions and to allow the creation of additional units of the currency which would be controlled. A multitude of cryptocurrencies exists across the world which includes Bitcoin, Ethereum and Primecoin amongst others. In 2014, a count revealed that there were more than 100 cryptocurrencies and since then this figure has been increasing

Bitcoin is the famous out of 700 virtual currencies in circulation on the Internet. The technology behind the Bitcoin is the blockchain. The blockchain has been defined as "a peer-to-peer public accounting system maintained by means of a distributed network of computes which requires no central authority or third parties acting as intermediaries."(BBVA Innovation Center 2017)

\footnotetext{
${ }^{1}$ Laboratoire de Recherche en Economie Quantitative du Développement (LAREQUAD), Tunis Business School, University of Tunis, Tunisia. We would like to thank Marc Avedissian, Anis Mnejja and Hichem Ben Fadhel for detailed feedbacks. Needless to say, all errors are the author's responsibility
} 
Blockchain operates with three main components:i) a transaction; ii) a transaction register; and iii) a system verifying and storing the transaction. Blocks are created with the use of an open-code software and information is registered as and when transaction happens. The block is responsible for the storing of sequential information on all the transactions happening in the chain. This pattern explains the derivation of the name "blockchain". The blockchain can be described as a public ledger whereby each transaction is recorded followed by a verification process. The blockchain ensures that transactions cannot be reversed and prevents its users from spending coins twice. In fact, most cryptocurrencies use the Bitcoin blockchain. The Bitcoin blockchain operates on a software which is open-ended, that is, any user can consult the code if desired. The process begins when the users firstly install the software on their computers or mobile devices. They would then be able to store the coins in a digital wallet. Afterwards, users can transfer money from their wallet to another user's one by making use of the addresses assigned with private and public encryption keys. Users forming part of the system of Bitcoin can observe the number of coins stored at a public Bitcoin's address, but they would not be able to link the addresses to a specific individual since these addresses are not connected to a name or a physical address. A specific feature about Bitcoin is that each address is used once ensuring security as per Nakomoto (2008)(BBVA Innovation Center 2017).

Historically, it was David Chaum $(1982,1985)$ who initially came up with the idea of a payment method being cryptographically secured ensuring privacy in the 1980s. He launched DigiCash in 1990. Nevertheless, DigiCash and Ecash resulted as failures. Almost thirty years later, there has been a wide range of cryptocurrencies with Bitcoin leading the market. Satoshi Nakamoto created Bitcoin in 2008 and its value grew quickly reaching US\$27 per Bitcoin in 2009. In 2017, the value of Bitcoin stood over US\$7,500. The idea of the Bitcoin as well as other currencies proved that to monitor expenditure, the role of any central authority is not needed so far, the parties involved have agreed for the transaction. It can be claimed that cryptocurrencies such as Bitcoin has gained importance by demonstrating its potential to run in the real world. Bitcoin has proved that many banks, investment companies, trading firms and even retailers have adopted cryptocurrencies as legitimate modes of payment and form of currency since they have real purchasing power.

Mention is not to be made on the fact that Bitcoin was criticized when initially launched in 2009. It has been argued that cryptocurrency could lead to money laundering cases and tax evasion. This was further proved in January 2013 whereby fluctuations were recorded for the Bitcoin. According to the International Monetary Fund about virtual currencies, Bitcoin has gained power since. It was stated that virtual currencies and their technology could provide faster and less costly financial services. This represented a toolwhich would allow further inclusion in the financial platform for a developing world. Many are of the opinion that Bitcoin has entered a fully developed phase after almost more than six years although this technology witnessed some irregularities and cases of fraud.

Blockchain technology is currently being supported by the banking sector. According to the research conducted by (BBVA Innovation Center, 2017), it has been reported that the whole financial system could be replaced by a decentralized structure. The rationale is that financial assets such as securities, bonds, derivatives and even loans are being transacted electronically. The updated innovation promotes the use of token for the marketing and storage of assets such as securities, bonds, motor vehicles, houses and even consumable goods.

Policy makers and regulators are once again facing the challenge in terms of framework to be put in place with an innovation that was inexistent until recently. The concept can be compared to the "egg and chicken", that is, whether the adoption of Bitcoin and blockchain push the pace of regulations or vice-versa. According to (Catalini C. and Gans Joshua S., 2017), the considerable fluctuations in the bitcoin prices demonstrate that the market does not provide stability. The high volatility proves that Bitcoin cannot act as a reliable store of value. According to (Harvey Campbell R., 2016), merchants who normally accept Bitcoin as a mode of payment would immediately exchange the coin for the conventional currency due to the risk associated. 
The non-acceptance of Bitcoin can be explained by the switching costs and networks effects as per Luther (2015) (Finextra Research Ltd, 2016). These switching costs refer to the transition costs occurring when shifting from the traditional monetary payment systems to Bitcoin. The transition costs are those costs associated with the improvement of vending machines and automatic teller machines. It has been argued that intermediaries such as central and commercial banks spend substantially on the maintenance costs. It has been found that these maintenance costs can be saved only when governments adopt cryptocurrencies allowing the switching costs to be reduced. The network effects as per Plassaras (2013) (Finextra Research Ltd, 2016) refer to positive externalities by which customers increasingly accept Bitcoin and the more valuable the virtual currency becomes. The reality is that the network effects for Bitcoin are not large enough as compared to those of the traditional currencies. When the barriers such as switching costs and network effects would be resolved, the persuasion process for consumers and merchants would still need to be worked upon.

It was stated by Hauschildt (2012) (Finextra Research Ltd, 2016) that the major barrier towards the adoption of Bitcoin is the lack of regulation. It has been put forward that in case the International Monetary Fund becomes the regulator, it can avoid any possible economic disaster. It is a reality that the Bitcoin system does not allow the provisions of loans or other banking facilities, making the system less attractive. It has been recommended by Deloitte Consultants (Syndicated News SNN.BZ, 2016) that policy makers and regulators collaborate along with the stakeholders because this imminent technology could cause disruption in the financial services sector as well as technological sector.

The purpose of this paper is to assess the possible future of cryptocurrency in emerging markets while focusing on the case of Mauritius. More precisely, we aim i)to identity the sustainability of cryptocurrency in Mauritius, ii) to compare the risk of cryptocurrency with conventional banking system, iii)to assess the impact of cryptocurrency and iv)to recommend the pitfalls of cryptocurrency and the possible framework needed to increase credibility in cryptocurrency.

The analysis is based on a survey conducted among the population in general. The analysis will help to recommend the main stakeholders with respect to the implementation of cryptocurrency in Mauritius.

The reminder of the paper is organized as follows. Section II lays out the methodology used in this paper. Section III describes the data and analyses the results. Section IV presents the main recommendations and concludes.

\section{Methodology}

Our methodology is based on an empirical testing of some theoretical hypothesis. Hence we first start by explaining these theoretical findings to lay out later the empirical methodology.

\section{Theoretical framework}

\section{Perceived usefulness}

As per David et al. (1989) (Naicken L. 2012), perceived usefulness (PU) is defined as the performance of consumers towards technology is possibly to increase based on subjective probability. Through perceived usefulness, it has been found that a positive correlation exists between attitude and usage intention. Factors such as efficiency and effectiveness are normally considered when dealing with perceived usefulness. PU determines the rate of adaptation to innovation.

According to (Bhattacherjee A. 2002), the willingness of an individual will determine the perceived use of a specific system in place. It has been proven that perceived usefulness and ease of use will have an impact on behavioral intention - both directly and indirectly. Chen et al. (2003)(Lee Hyun-H., Fiore A. \& Kim J. 2006) 
put forward the argument that PU affects usage intention directly. The following hypothesis is developed based on PU:

Hypothesis 1: Perceived usefulness is directly linked to the adoption of cryptocurrency

\section{Perceived Ease of Use}

David et al. (1989) (Wessels L. and Drennan J. 2010) defined the ease of use as being the extent to which a user is prepared to use the system for which little effort is needed while doing so. The long-term use of a specific innovation is affected by PU as well as ease of use. According to (Curran James M. and Meuter Matthew L. 2005), there exists a positive relationship between the intention of using a specific technology and ease of use. Consequently, it can be deduced that ease of use affects the intention to use an innovation and the attitude.

Therefore, the hypothesis below can be developed:

Hypothesis 2: The adoption of cryptocurrency is directly affected by perceived ease of use of cryptocurrency/blockchain

\section{Need for personal interaction}

As per(Dabholkar Pratibha A. 1996), the need for personal interaction is essential for customers especially when dealing with some services provided by the banks. The creation and retention of personal contact rely on the need of personal interaction.

The interpersonal interactions between customers and service providers are determined by the level of service provided as stated by (Curran James M. and Meuter Matthew L. 2005). Personal interaction is valued by many customers. A negative relationship has been found between the need for interaction and the intention of use by (Wessels L. and Drennan J. 2010). It can be derived that those customers who are less used to technological innovation are the ones needing personal interaction. The following hypothesis can be derived:

Hypothesis 3: Cryptocurrency is inversely related to the need for personal interaction

\section{Perceived Risk}

As per (Taylor James W. 1974), the theory of perceived risk is defined as the factors influencing the decisionmaking process and the behavior of customers. Since the beginning of the twenty-first century, the initial definition of perceived risk has been changed. This is mainly because customers' behavior is changing. Fraud and the quality of the product were mostly identified when speaking of perceived risk. Nevertheless, perceived risk now entails the psychological, financial, social and physical risks when dealing with a new technology or innovation as stated by (Forsthe S. 2003).

Studies have revealed that the adoption of cryptocurrency is affected by the perception of risk. Indeed, with the absence of intermediary, the perceived risk is high for the blockchain technology.

In addition, the concept of perceived self-efficacy has emerged. As claimed by (Gefen D., Karahanna E. and Straub Detmar W. 2003), perceived self-efficacy can be described as the extent to which customers are confident via his/her expertise and experience while using a specific technological innovation.

As a result, it has been observed from studies that perceived risk has a negative impact on the attitude and usage of the cryptocurrency. In simpler terms, the risk of using cryptocurrency is high, the attitude towards this innovation is negative and hence the willingness to use this technology will be low. The following hypothesis can be formulated: 
Hypothesis 4: Perceived risk indirectly affects the adoption of cryptocurrency.

\section{Perceived Cost}

Perceived cost is defined as the extent to which a customer is of the impression that using a technology such as cryptocurrency will cost money. Very often, the adoption of cryptocurrency will depend on the cost of purchasing and using such technology. Low costs or services free of charge are the factors which encourage the use of cryptocurrency. Studies have revealed that there exists a negative relationship between perceived costs and the probability to use cryptocurrency. Supposed the cost of using cryptocurrency is low then the customers are most likely going to opt for the use of such technology. The below hypothesis can be developed:

Hypothesis 5:The use of cryptocurrency is directly linked to perceived cost of use

\section{Compatibility with needs and standard of living}

In 1962, Everett Rogers, a professor of communication studies developed The Innovation Diffusion Theory (IDT). This theory in this context enables to have a proper definition of compatibility. It is defined as the extent to which blockchain is being developed to meet the actual needs to the customers and their lifestyle.

It has been found by (Hourahine B., Howard M. 2004) that the customers' needs are not met due to the failure of more than two third of the financial transaction services. The reason behind such failure is the fact that the traditional delivery channels are not widespread. It has beenfound through research that high compatibility accounts for the increased probability in adopting the cryptocurrency.

Should the needs of the customers not be met satisfactorily, these customers tend to avoid intermediaries to conduct their transactions. Based on the studies conducted, it was revealed that compatibility and the intention to use a new technology are positively related. It can therefore be concluded that the probability of customers adopting cryptocurrency will be high if the level of compatibility of the technology is high associated with the needs and demands of the customers. The following hypothesis can be developed:

Hypothesis 6: The compatibility with lifestyle and needs has a direct impact on the use of cryptocurrency.

\section{$\underline{\text { Trust }}$}

According to (Das T. K. and Teng Bing-S. 2001) trust is defined as the possibility to trust a business partner who is worth being trusted. It is to be noted that perceived risk and trust are concepts being closely related influencing the use of cryptocurrency.

Trust is a key term for banks. If customers trust the banking system which is stable and efficient, they will less likely adopt cryptocurrency. Cryptocurrency involves only the two parties performing the financial transactions without the presence of an intermediary. In Mauritius, banks have been able to observe the customers' perception of risks and have devised the means to eliminate the possible risks. It is an undeniable fact that traditional banking remains less risky than using cryptocurrency. Consequently, it can be hypothesized that:

Hypothesis 7: Trust has a negative impact on the use of cryptocurrency

\section{Credibility}

(Erdem T. and Swait J. 2004) defined credibility as "the ability to trust a system and its capacity in transferring and doing transactions." 
Credibility has also been associated with the security aspects and privacy threats involved using cryptocurrency. Without the presence of an intermediary means that the customers are subject to credit risk or counterparty risks. Many customers do not feel at ease to bypass the use of an intermediary when conducting business. Very often, the customers might not want to share their personal data, and this could lead to AML/KYC issues.

Lack of credibility influences the possibility of using cryptocurrency. Thus, the following hypothesis can be developed:

Hypothesis 8: Credibility directly affects the adoption of cryptocurrency.

\section{Data Collection Method}

For data analysis, normally two types of data can be used. Primary data has often been collected using the survey method. It ensures that the data collected for study purposes reflect the research objectives. Secondary data could have also been another type of data which is easily accessible to many users.

Primary data is viewed as being reliable, accurate and updated. It has got some disadvantages since collecting primary data can be expensive and time-consuming. It is time-consuming since the preparation of interviews and the analysis of the data.

For the purpose of data analysis, surveys were collected from the respondents using an online questionnaire. The online questionnaire was sent to the potential respondents. An email invitation containing a hyperlink was sent to the potential respondents to complete the self-administered online questionnaire.

\section{Questionnaire Design}

$>$ Layout

Prior to designing the questionnaire, several factors had to be considered. The questionnaire had to be captivating to encourage the participants to respond. The respondents were provided with a brief summary of the research. The summary mainly focused on the aim of the survey and also emphasized on the aspects such as anonymity and confidentiality of the respondents. A note was included to thank the respondents for their participation.

$>$ Sequence of questions

The questionnaire consists of only closed-ended questions. The answers were preset to help the respondents to complete the questionnaire. The use of a likert scale with five points whereby " $1=$ strongly disagree", " $2=$ Disagree", " $3=$ Neutral", " $4=$ Disagree" and "5=Strongly Disagree". The respondents were given the statements and they had to choose the degree to which they agree and disagree to the given statements.

$>$ Format of Questionnaire

The questionnaire was divided into several sections to collect accurate data:

Section 1 - Level of Awareness and Usage

Questions 1-4 were set to analyse the level of awareness and usage.

Section 2 - Perceived Usefulness of Cryptocurrency

Question 5 tries to determine whether individuals perceive cryptocurrency to be advantageous.

Section 3 - Perceived Ease of Use when using Cryptocurrency

Question 6 evaluates the possible hurdles to be face with while using cryptocurrency.

Section 4 - Perceived Risk and Cost

Question 7 measures the level to which existing and new customers perceive this technology to be risky and expensive.

Section 5 - Compatibility with Lifestyle and Needs 
Question 8 aims to understand whether cryptocurrency can integrate the lifestyle, needs and values of Mauritians.

Section 6 - Need for Personal Interaction

Question 9 has been set to gauge the extent to which respondents prefer personal interaction while performing their financial transactions.

Section 7 - Perceived Trust

The degree of trust required by the customers with regards to cryptocurrency is being dealt under Question 10.

Section 8 - Confidentiality

Question 11 focuses on security aspect while using cryptocurrency.

Section 9 - Recommendation

Questions 12 and 13 have been set to determine the possible future of cryptocurrency in Mauritius.

Section 10 - Demographic Profile

Questions 14 - 18 gather personal data on the participants to the questionnaire such as age group, gender, level of education, occupation and salary.

\section{List of Hypotheses}

Hypothesis 1:

$\mathrm{H}_{\mathrm{o}}$ : The age group of the participants has no influence on the perceived risks to use cryptocurrency (Questions 15 and 7 (b))

$\mathrm{H}_{1}$ : The age group of the participants has an influence on the perceived risks to use cryptocurrency (Questions 15 and 7 (b))

Hypothesis 2:

$\mathrm{H}_{\mathrm{o}}$ : The perceived trust to use cryptocurrency is not influenced by the gender of respondents (Questions 10 (a) and 14)

$\mathrm{H}_{1}$ : The perceived trust to use cryptocurrency is influenced by the gender of the respondents (Questions 10 (a) and 14)

Hypothesis 3:

$\mathrm{H}_{\mathrm{o}}$ : The perceived usefulness of cryptocurrency does not depend on the level of education (Questions 5 (a) and 16)

$\mathrm{H}_{1}$ : The perceived usefulness of cryptocurrency depends on the level of education (Questions 5 (a) and 16)

Hypothesis 4:

$\mathrm{H}_{\mathrm{o}}$ : The perceived cost for the use of cryptocurrency does not depend on the monthly income of the respondents (Questions 7(d) and 18)

$\mathrm{H}_{1}$ : The perceived cost for the use of cryptocurrency depends on the monthly income of the respondents (Questions 7(d) and 18)

Hypothesis 5:

$\mathrm{H}_{\mathrm{o}}$ : There exists no relationship between the occupation of the respondents and compatibility with needs and lifestyle (Questions 17 and 8(b))

$\mathrm{H}_{1}$ : There exists a relationship between the occupation of the respondents and compatibility with needs and lifestyle (Questions 17 and 8(b)) 


\section{Data and Results}

The data collected from 71 out of 100 participants was analysed using SPSS version 20.

Below is a statistical description of the data collected.

\section{Demographic Profile of Participants}

Under question 14, the participants were required to choose their gender. It has been revealed that the female counterparts represented the majority from the sample which is $77 \%$. As per the official statistics on the Mauritian population, it has been deduced that there are more female citizens than male ones. This clearly explains the response rate.

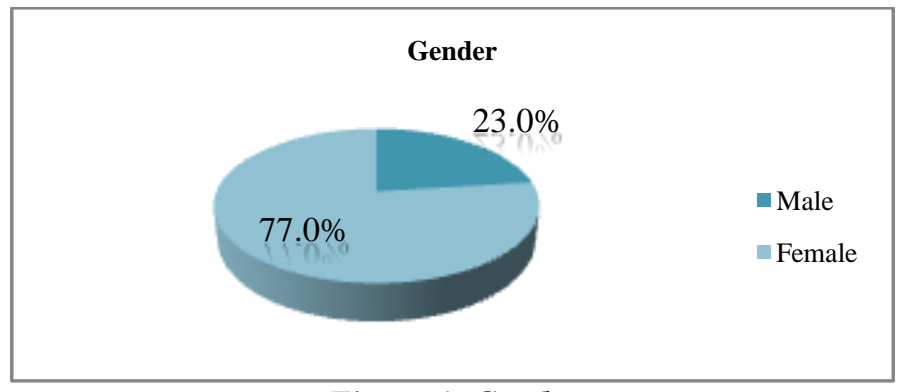

Figure 1: Gender

Table 2: Gender

\begin{tabular}{|c|c|c|c|c|}
\hline \multicolumn{5}{|c|}{ Gender } \\
\hline & Frequency & $\%$ & Valid \% & Cumulative \% \\
\hline Female & 55 & 77 & 77.0 & 77.0 \\
\hline Male & 16 & 23 & 23.0 & 100.0 \\
\hline Total & 71 & 100.0 & 100.0 & \\
\hline
\end{tabular}

Question 15 dealt with the age group of the participants.

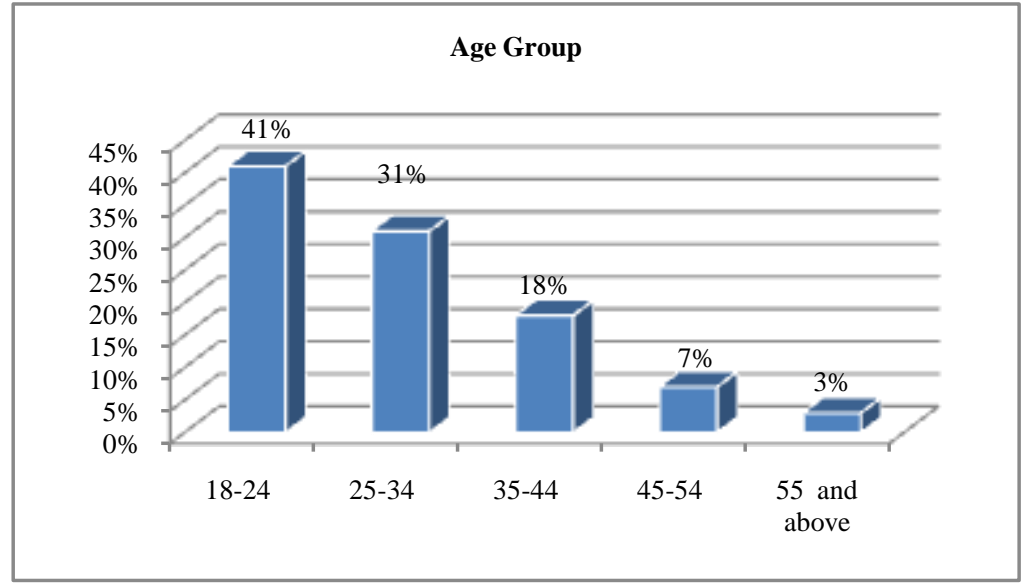

Figure 2: Age Group 
Table 1: Age Group

\begin{tabular}{|c|c|c|c|c|}
\hline \multicolumn{3}{|c|}{ Age Group } & \\
\hline Age & Frequency & $\%$ & Valid \% & Cumulative \% \\
\hline $18-24$ years & 29 & 41.0 & 41.0 \\
$25-34$ years & 22 & 31.0 & 31.0 \\
$35-44$ years & 13 & 18.0 & 18.0 & 72.0 \\
$45-54$ years & 5 & 7.0 & 7.0 & 90.0 \\
55 years and above & 2 & 3.0 & 3.0 & 100.0 \\
\hline
\end{tabular}

Based on the data collected, it is deduced that most of the respondents is the category of 18-24 years (41\%). This can be explained by the fact that technology plays a predominant role in the lives of the young generation. This generation is very versatile with the use of technology. The other age group that recorded a high response rate is among 25-34 years. The workers form part of this age group and they are the ones with little spare time for other activities.

Question 16 was set to assess the level of education of the respondents.

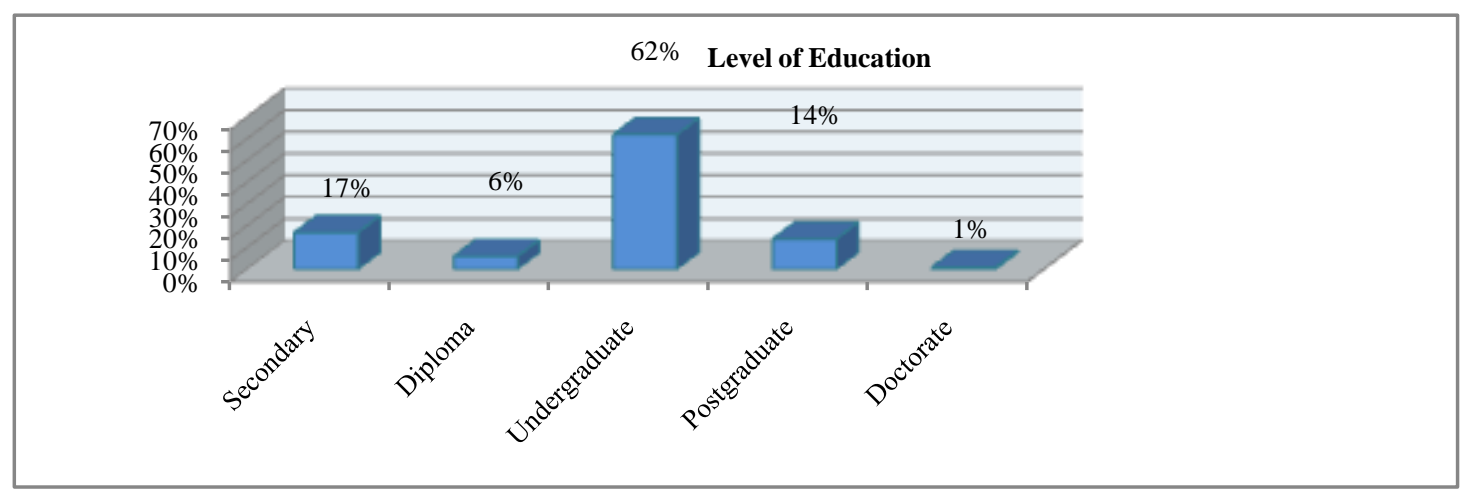

Figure 3: Level of Education

Table 2: Level of Education

\begin{tabular}{|l|c|c|c|c|}
\hline HighestLevel of Education & Frequency & \% & Valid \% & Cumulative \% \\
\hline Diploma & 4 & 6 & 6 & 6 \\
Doctorate & 1 & 1 & 1 & 7 \\
Postgraduate & 10 & 14 & 14 & 21 \\
Secondary & 12 & 17 & 17 & 38 \\
Undergraduate & 44 & 62 & 62 & 100.0 \\
Total & $\mathbf{7 1}$ & $\mathbf{1 0 0 . 0}$ & $\mathbf{1 0 0 . 0}$ & \\
\hline
\end{tabular}

It has been noted from the overall sample that the respondents' highest level of education falls under the undergraduate and secondary level with $62 \%$ and $17 \%$ respectively. The literacy rate in Mauritius has reached a reasonable level. However, it can also be seen that only $14 \%$ represents the ones who had completed postgraduate studies. 
Question 17 was related to the current occupation of the participants.

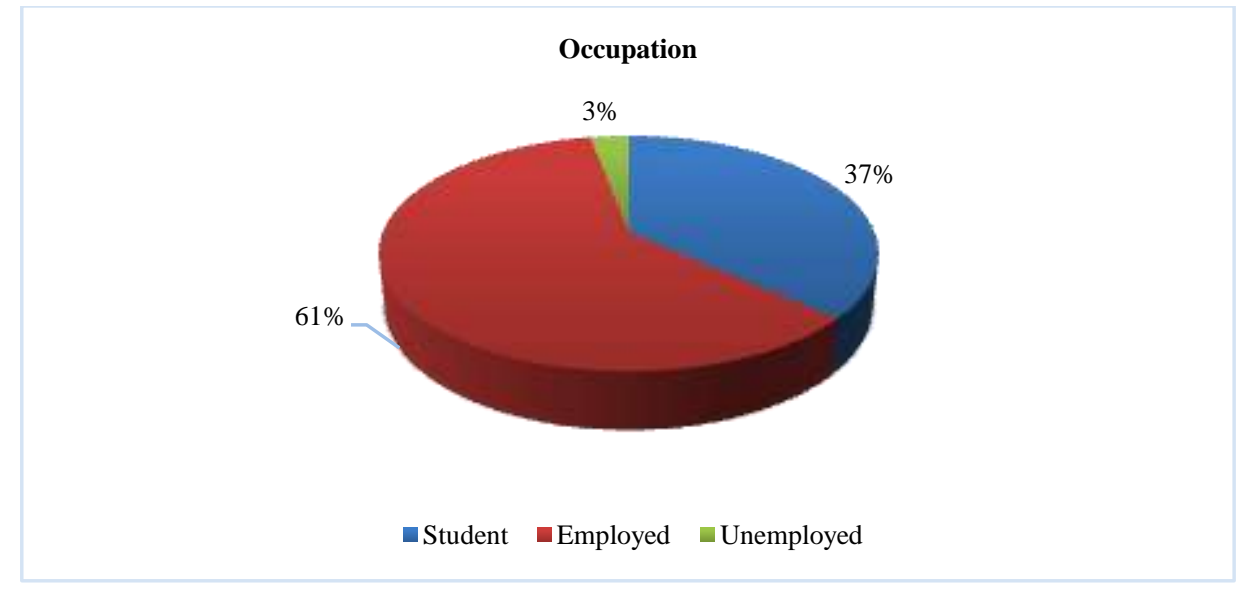

Figure 4: Occupation

It can be seen from the data collected that most respondents were employed individuals (61\%) and students (37\%). This can be explained by the fact that the online questionnaire was circulated via a link to colleagues and tertiary students as well. The $3 \%$ accounts for the unemployed.

The respondents were requested to choose their monthly income range for question 18 .

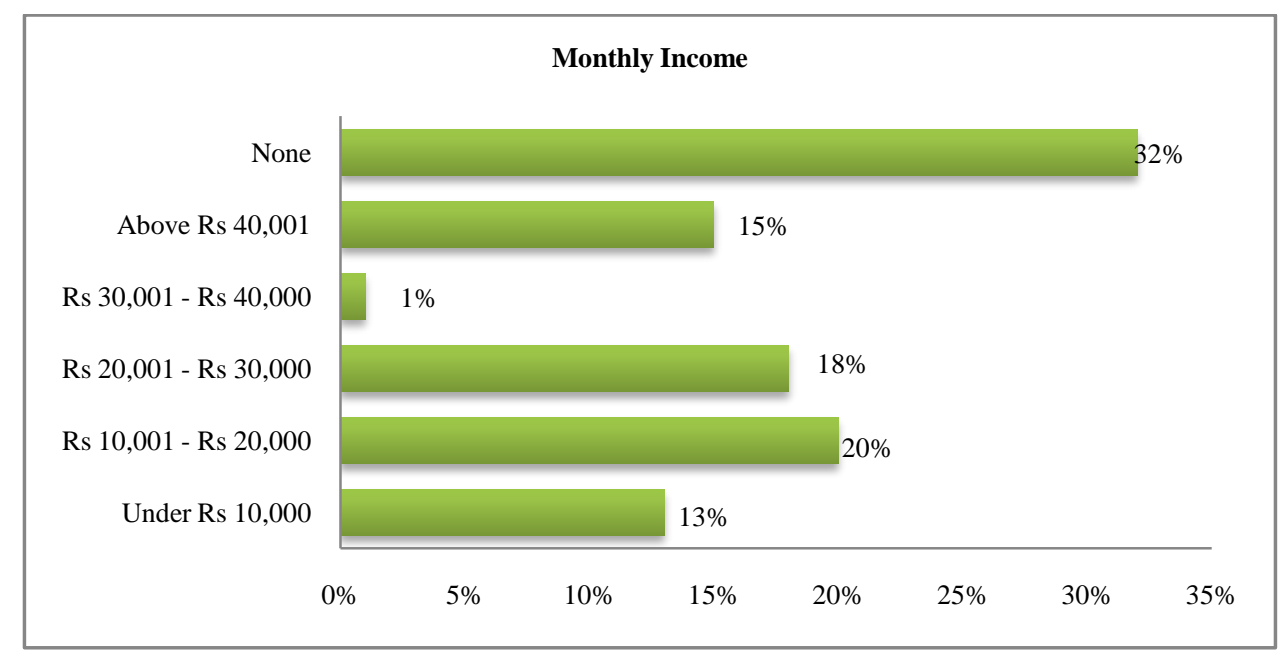

Figure 5: Monthly Income

The monthly income range of the respondents was illustrated on the above figure. The highest figure (32\%) represents those who do not earn any income. This reflects the number of students who participated to the completion of the questionnaire. The income range with a high percentage is between Rs 10,001 - Rs 20,000. This range is quite high since when the university leavers join the work environment and due to their low exposure to the work field, their salary level tends to be low. With experience, some earn between Rs 20,001 Rs 30,000 (18\%). It cannot be denied that with the level of experience and education level, some workers earn above the range of Rs 40,001 represented by $15 \%$. 


\section{Level of Awareness and Usage}

It has been observed that 62 respondents out of the total of 71 respondents had heard of cryptofinance. Fintech has gained significant importance in Mauritius.

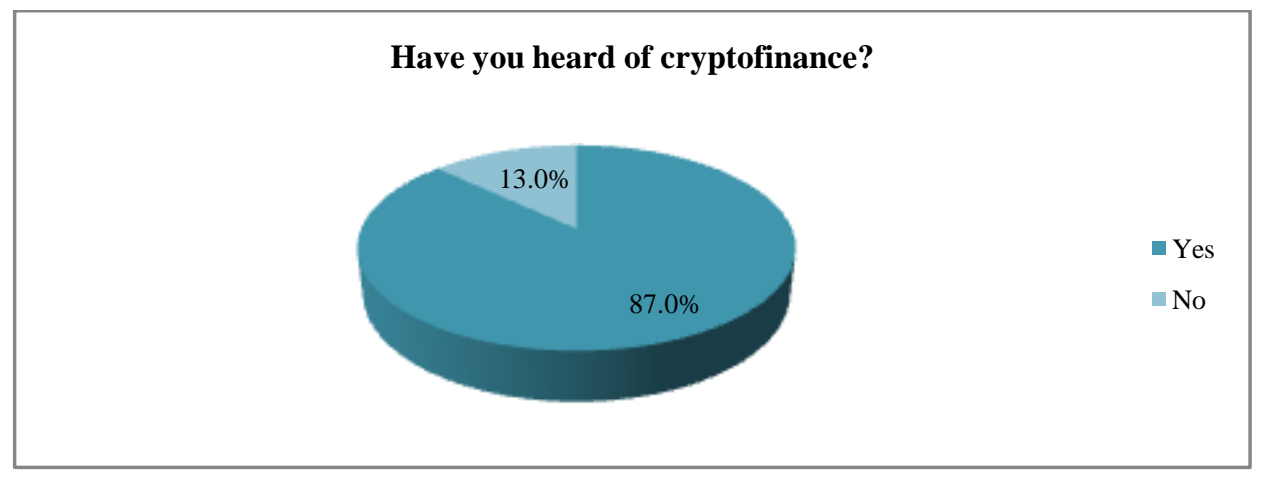

Figure 6: Awareness of Cryptofinance

The above chart gives an indication on the level of awareness on cryptofinance. $87 \%$ of the respondents demonstrates that individuals have got a financial literacy. The $13 \%$ who are not aware of this innovation might be because they are not in the financial field and tend to focus on other areas of studies.

Question 2 was related to the access to Blockchain.

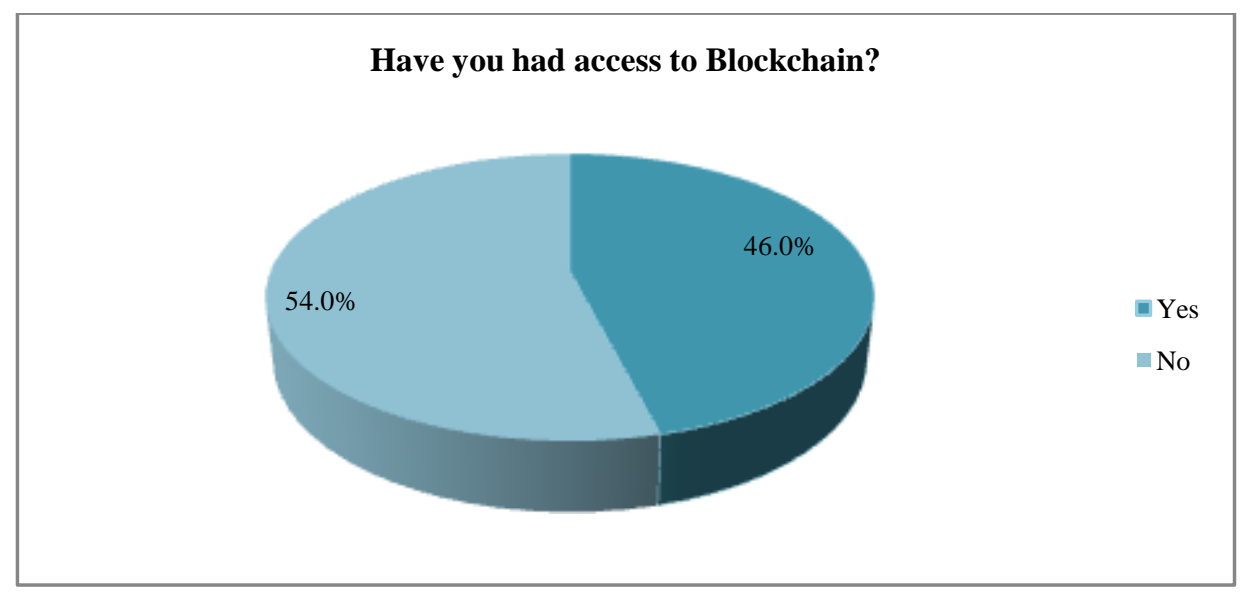

Figure 7: Access to Blockchain

The figure above clearly shows that some of the respondents (46\%) being in the financial sector have had access to Blockchain. The rest of the respondents $(54 \%)$ have not had access. It is a reality in Mauritius that individuals are not used to new technological tools and prefer the traditional way of banking. It is also a fact that to have access to Blockchain, one must have access to internet and show interest in using the technology.

Question 3 dealt with the assessment of whether the participants were aware of the financial institutions offering cryptofinance. 


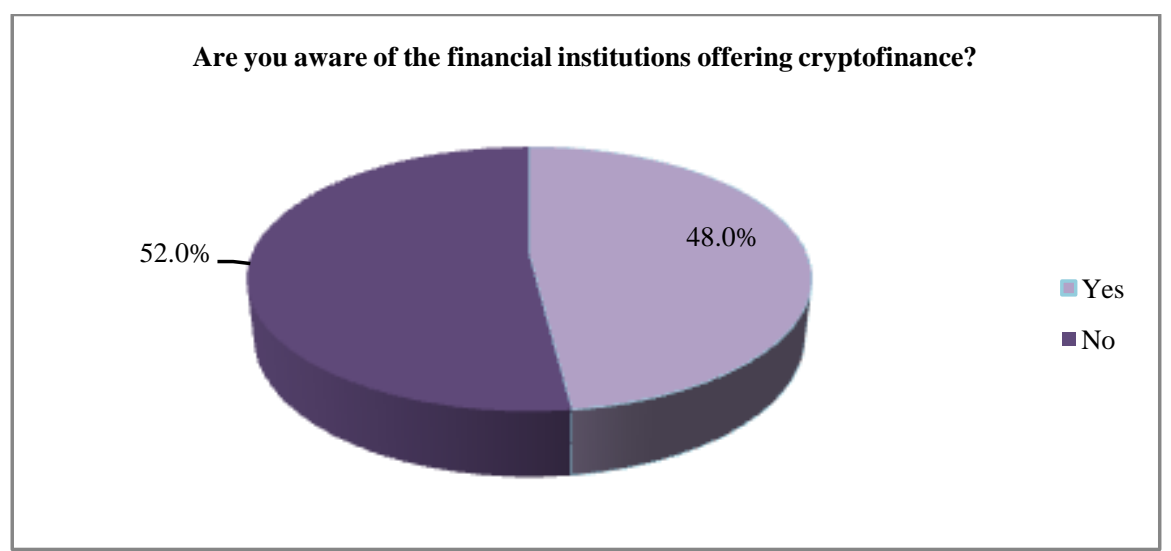

\section{Figure 8: Financial Institutions offering cryptofinance}

The financial institutions offering cryptofinance are known to the respondents although they are not necessarily using blockchain. Following an increase in financial literacy in Mauritius, more and more individuals are interested in using Fintech. Hence, this can be reflected in the $48 \%$ being aware of same. The remaining $52 \%$ are not aware. This could be because certain customers are risk averse and might not be willing to adopt this new technology. They actually feel more secured with the traditional way of performing their banking transactions.

Question 4 was set to evaluate the financial institutions that the respondents use to carry out their financial transactions.

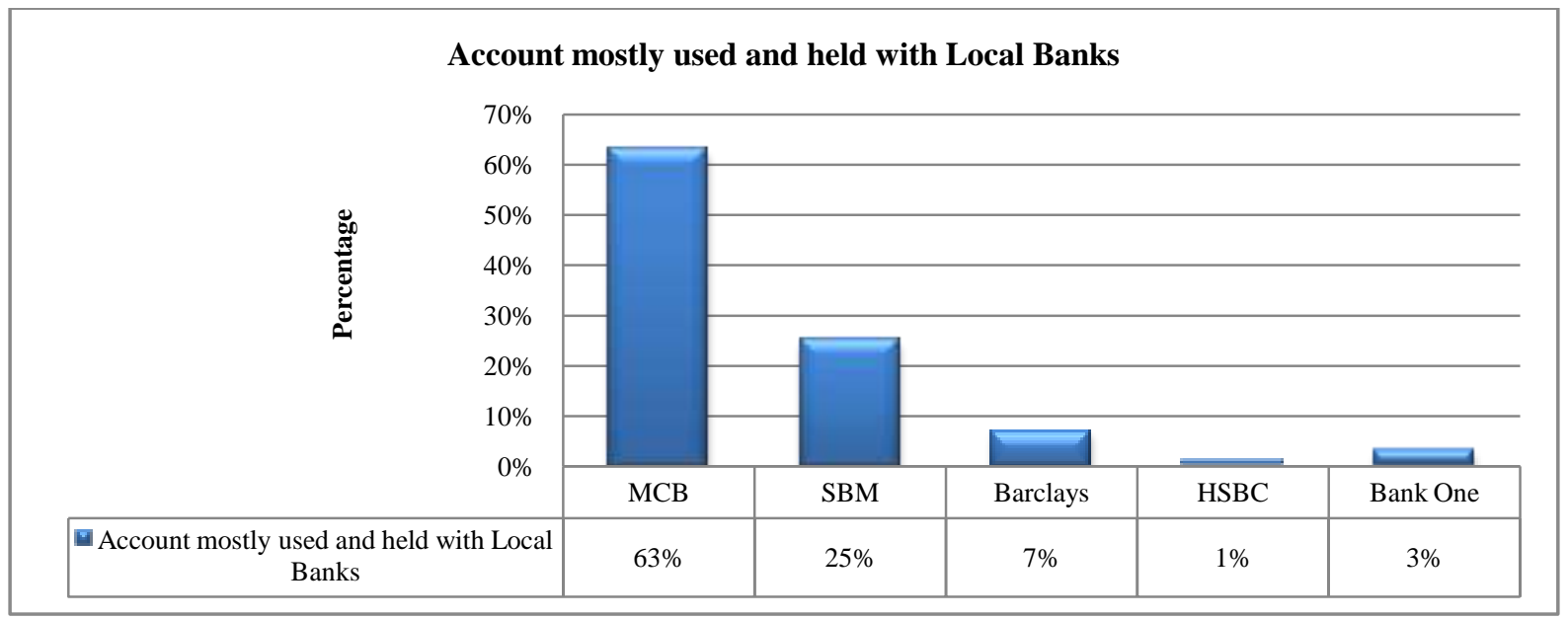

Figure 9: Accounts used and held with Commercial Banks 
Table 5: Accounts mostly used

Please name the account with which you carry out your financial transactions from the list below (mostly used one):

\begin{tabular}{|c|c|c|c|c|c|}
\hline & & Frequency & $\%$ & Valid \% & $\begin{array}{c}\text { Cumulative } \\
\%\end{array}$ \\
\hline \multirow{7}{*}{ Valid } & Bank One & 2 & 2 & 2 & 1.5 \\
\hline & Barclays & 5 & 4 & 4 & 5.1 \\
\hline & HSBC & 1 & 1 & 1 & 5.9 \\
\hline & Mau Bank & 3 & 2 & 2 & 8.1 \\
\hline & MCB & 91 & 67 & 67 & 75 \\
\hline & SBM & 32 & 24 & 24 & 100 \\
\hline & Total & 136 & 100 & 100 & \\
\hline
\end{tabular}

It has been observed from the table and chart above that the Mauritius Commercial Bank Limited (MCB) is one of the leading banks in Mauritius whereby 67\% of Mauritians hold accounts and carry out their financial activities. This can be explained by the fact that MCB is viewed to be a trustworthy bank based on the years of existence and hence the probability that MCB will default is quite low. MCB maintains its position among the top-ranking banks yearly in Mauritius. With respect to the State Bank of Mauritius (SBM), it remains in the second position. SBM is viewed by many customers as being the bank which is safe to transact. This trend is because Government holds share in this bank and its default probability is very low. As for the other commercial banks, a lesser proportion of customers hold accounts with them. The reason behind these figures might be due to the preference of the customers.

\section{PerceivedUsefulness of Cryptocurrency}

Question 5 being "How will cryptocurrency be advantageous according to you?" was set to determine the extent to which the participants would benefit from the use of cryptocurrency.

Table 6: Perceived Usefulness of Cryptocurrency

\begin{tabular}{|c|c|c|c|c|c|c|}
\hline Benefits & $\begin{array}{c}\text { StronglyDisagree } \\
\%\end{array}$ & Disagree \% & $\begin{array}{c}\text { Neutral } \\
\%\end{array}$ & $\begin{array}{c}\text { Agree } \\
\%\end{array}$ & $\begin{array}{c}\text { StronglyAgree } \\
\%\end{array}$ & $\begin{array}{c}\text { Total } \\
\%\end{array}$ \\
\hline $\begin{array}{l}\text { Cryptocurrency is simple and } \\
\text { convenient to use. }\end{array}$ & 6 & 10 & 27 & 41 & 17 & 100 \\
\hline Accessible round the clock. & 3 & 8 & 15 & 39 & 34 & 100 \\
\hline $\begin{array}{l}\text { Transactions can be performed } \\
\text { quicker and without hurdle. }\end{array}$ & 4 & 4 & 27 & 44 & 21 & 100 \\
\hline $\begin{array}{l}\text { Explanation on usage of this } \\
\text { technology is available. }\end{array}$ & 11 & 10 & 38 & 32 & 8 & 100 \\
\hline
\end{tabular}




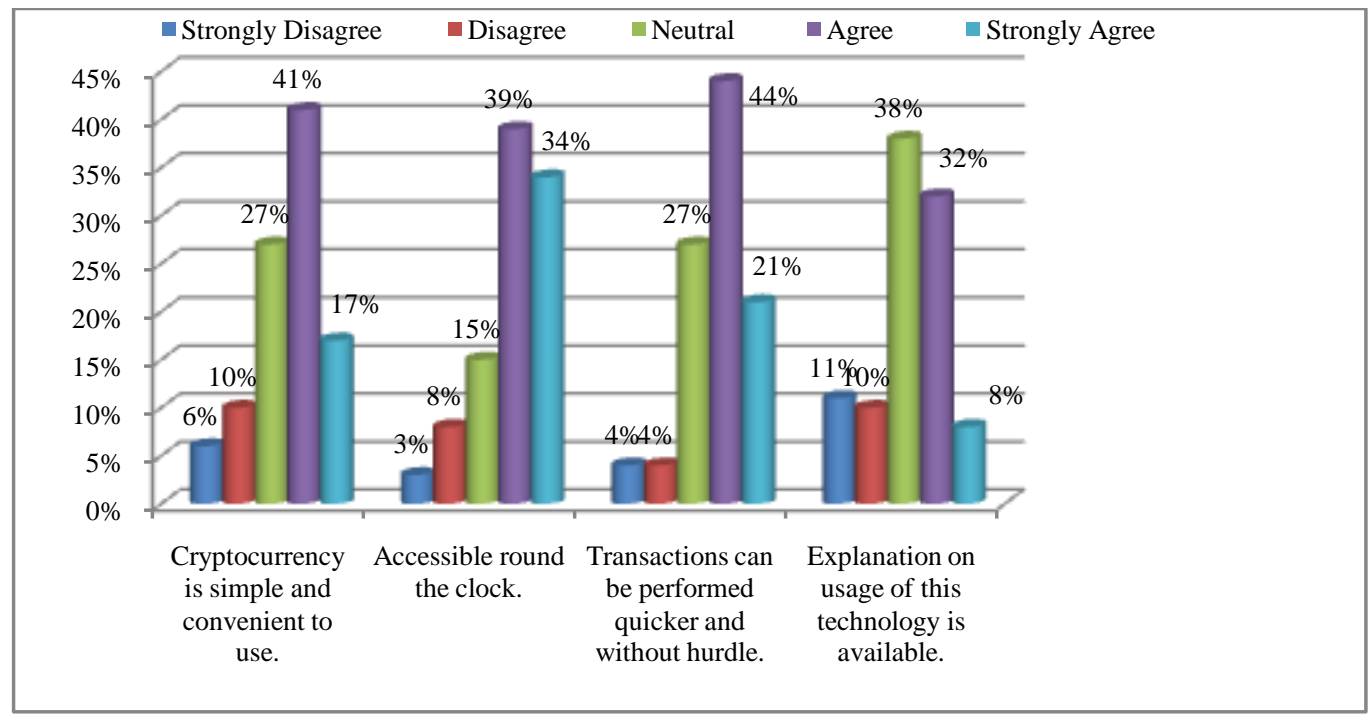

Figure 10: Perceived Usefulness of Cryptocurrency

It has been revealed through the chart and table above that $44 \%$ of the respondents are of the opinion that financial transactions can be performed quicker and without hurdle. This is because there is the absence of the financial intermediaries while using cryptocurrency. $41 \%$ of the participants agree that cryptocurrency is simple and convenient to use. Cryptocurrency is simple to use provided that the users have understood the mechanism and are willing to be using this technology. $39 \%$ of the respondents are aware that using cryptocurrency is possible on a 24-hour basis unlike the traditional banking system. Only $32 \%$ agreed that the required explanation on the usage of this technology is available. It is a reality that advertising on the use of cryptocurrency is not carried out by the financial institutions offering this service.

\section{Perceived Ease of Use when using Cryptocurrency}

Question 6 is associated with the ease of use when using cryptocurrency - "According to you, what might be the possible difficulties encountered when using cryptocurrency?"

Table 7: Perceived Ease of Use when using Cryptocurrency

\begin{tabular}{|l|c|c|c|c|c|c|}
\hline \multicolumn{1}{|c|}{ Difficulties } & $\begin{array}{c}\text { StronglyDisagree } \\
\%\end{array}$ & Disagree \% & $\begin{array}{c}\text { Neutral } \\
\%\end{array}$ & $\begin{array}{c}\text { Agree } \\
\%\end{array}$ & $\begin{array}{c}\text { StronglyAgree } \\
\%\end{array}$ & $\begin{array}{c}\text { Total } \\
\%\end{array}$ \\
\hline $\begin{array}{l}\text { I do not feel secure since the } \\
\text { transactions are irreversible. }\end{array}$ & 6 & 23 & 28 & 31 & 13 & 100 \\
\hline Blockchain is not easy to use. & 15 & 48 & 24 & 13 & 0 & 100 \\
\hline $\begin{array}{l}\text { Blockchain is difficult to learn and } \\
\text { understand. }\end{array}$ & 20 & 41 & 30 & 8 & 1 & 100 \\
\hline
\end{tabular}




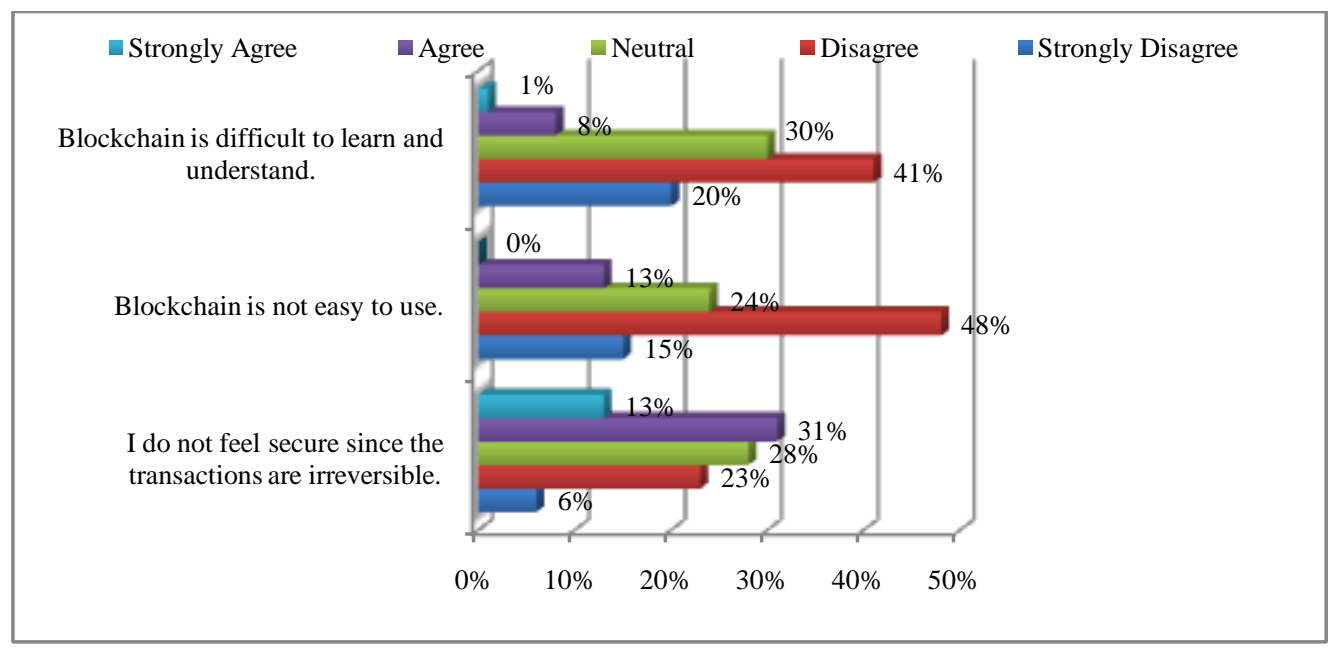

Figure 11: Perceived Ease of Use of Cryptocurrency

It can clearly be deduced that using cryptocurrency involves a degree of uncertainty level with $31 \%$ of the respondents who do not feel secure since the transactions cannot be reversed. $41 \%$ of the participants are of the view that Blockchain is not so difficult to learn and understand. However, $30 \%$ of the response rate was stated as neutral which means that the respondents could neither agree nor disagree to the fact that Blockchain is difficult to learn and understand. $48 \%$ of the respondents voted that Blockchain is easy to use and $24 \%$ of the respondents were not certain by voting 'neutral'. The candidates who voted neutral implies that they trust cryptocurrency only to a certain extent.

\section{Perceived Risk and Cost}

Question 7 was set to evaluate the level of riskiness the respondents associate with the use of cryptocurrency.

Table 8: Perceived Risk and Cost

\begin{tabular}{|c|c|c|c|c|c|c|}
\hline Features & $\begin{array}{c}\text { StronglyDisagree } \\
\%\end{array}$ & Disagree \% & Neutral \% & $\begin{array}{c}\text { Agree } \\
\%\end{array}$ & $\begin{array}{c}\text { StronglyAgree } \\
\%\end{array}$ & $\begin{array}{c}\text { Total } \\
\%\end{array}$ \\
\hline $\begin{array}{l}\text { It is not reliable: transactions may not } \\
\text { be completed due to network issues. }\end{array}$ & 6 & 27 & 48 & 16 & 3 & 100 \\
\hline $\begin{array}{l}\text { It is not secure: I can be faced with } \\
\text { financial loss and compliance issues. }\end{array}$ & 6 & 24 & 31 & 31 & 8 & 100 \\
\hline It is riskier than traditional banking. & 7 & 35 & 21 & 30 & 7 & 100 \\
\hline Transaction fees are low. & 6 & 31 & 45 & 12 & 6 & 100 \\
\hline
\end{tabular}




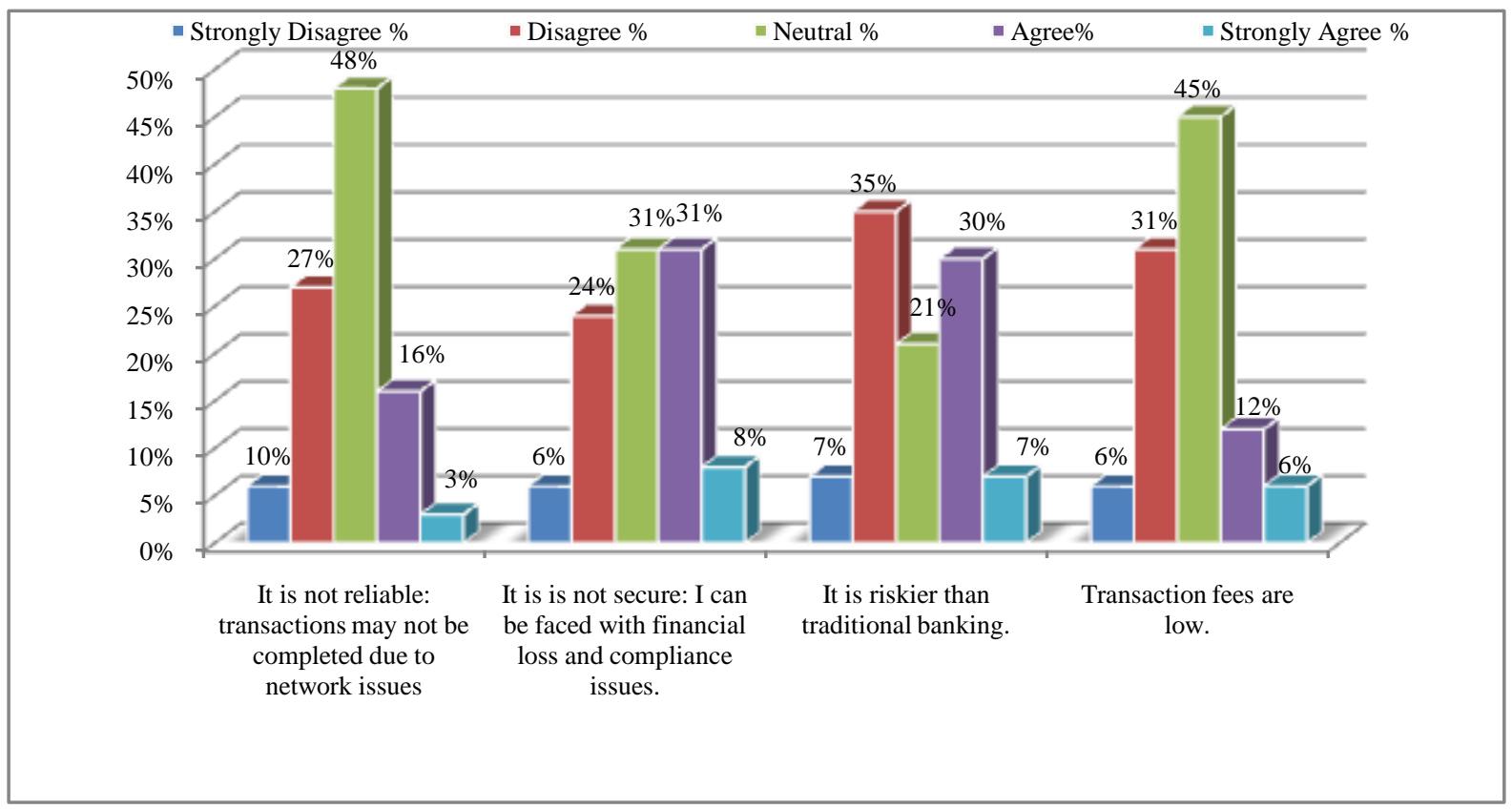

Figure 12: Perceived Risk and Cost

It can be observed from the chart and table above that the respondents are not certain of the reliability from the use of cryptocurrency ( $48 \%$ voted for 'neutral'). Regarding the security aspect, 31\% of the respondents confirmed that they could be faced with financial loss and compliance issues. The reality with the use of cryptocurrency is that illicit transactions could take place, and this could lead to serious financial losses. With regards to the compliance issues, this is likely to occur as the two parties transacting directly do not know the identity of the party and hence cannot conduct due diligence checks to ascertain the profile of the other party. With traditional banking, this is not the case. The banks are obliged to conduct due diligence checks on the customers they will take on-board as per the Bank of Mauritius Act 2004. 31\% of the respondents voted for neutral. This can be explained by the fact that they have not yet used blockchain and once used, they would have been in a better position to respond to this question.

$35 \%$ of the participants have disagreed that cryptofinance is riskier than traditional banking. It has once been the case in Mauritius whereby a commercial bank had crashed due to several non-compliance issues. For the risktaking customers, they would certainly disagree that cryptofinance is riskier than traditional banking.

As for the perceived costs, the respondents have neither agreed nor disagreed that the transaction costs are low. This might be because these respondents are not using cryptocurrency and hence are not aware of the related costs. Some respondents do not pay attention to the transaction costs although they are using cryptofinance. For these respondents, the costs might be considered as insignificant.

\section{Compatibility with Lifestyle and Needs}

Question 8 focuses on the extent to which the respondents might be willing to use cryptofinance being in accordance to their lifestyle and needs. 
Table 9: Compatibility with Lifestyle and Needs

\begin{tabular}{|l|c|c|c|c|c|}
\hline \multicolumn{1}{|c|}{ Statements } & $\begin{array}{c}\text { StronglyDisagree } \\
\text { \% }\end{array}$ & Disagree \% & Neutral \% & $\begin{array}{c}\text { Agree } \\
\%\end{array}$ & $\begin{array}{c}\text { StronglyAgree } \\
\%\end{array}$ \\
\hline $\begin{array}{l}\text { Cryptofinance could be useful for my } \\
\text { transactions. }\end{array}$ & 1 & 7 & 31 & 52 & 100 \\
\hline $\begin{array}{l}\text { The use of cryptofinance would suit my } \\
\text { lifestyle. }\end{array}$ & 3 & & & \\
\hline
\end{tabular}

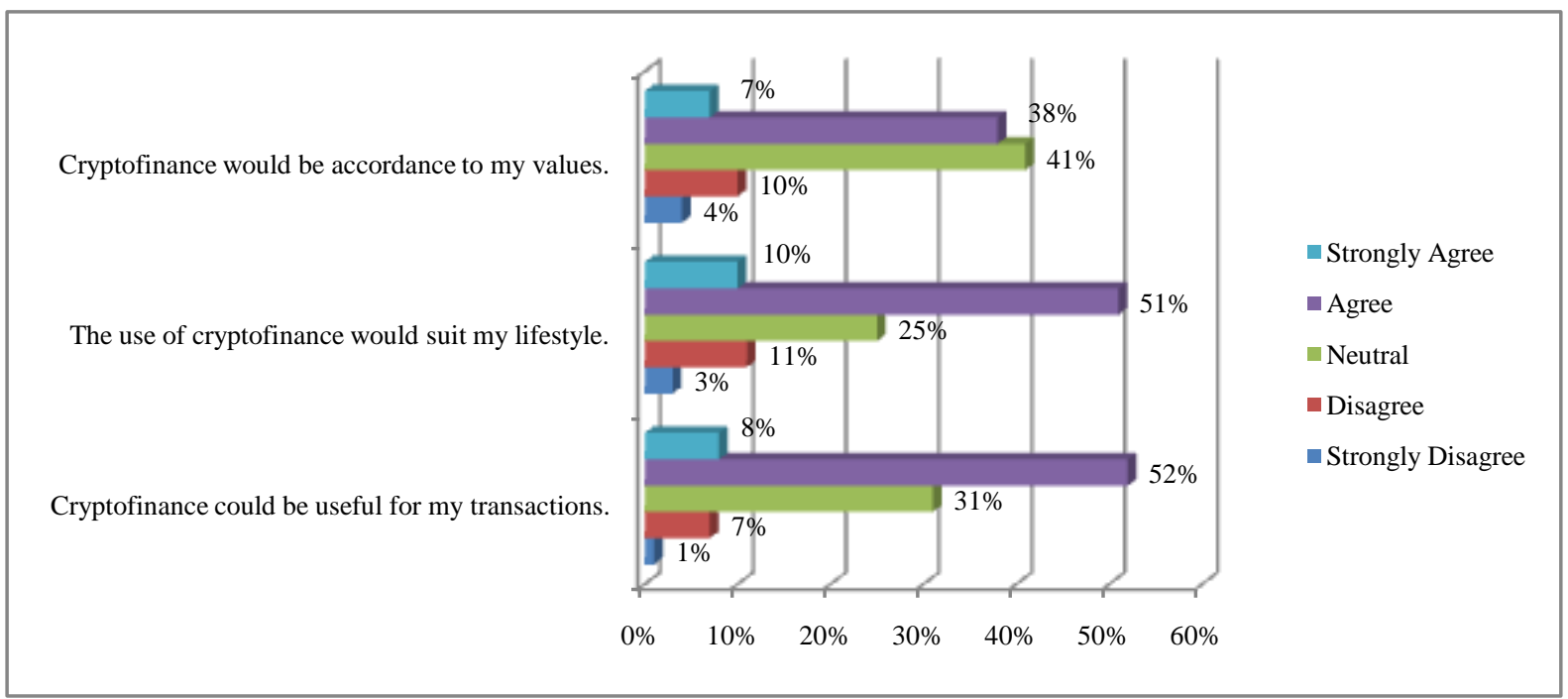

Figure 13: Compatibility with Lifestyle and Needs

From the above chart and table, 52\% of the respondents agreed that the use of cryptofinance could be useful to conduct their financial transactions. The second option ranked is Blockchain which would suit the lifestyle of the respondents $(51 \%)$. The reason behind this response rate could be the fact that the working population and students no longer have time to wait for long hours in view to completing their banking transactions. With cryptocurrency being available round the clock and accessible to all, many prefer to adopt cryptofinance. Some respondents have neither agreed nor disagreed to the section whereby cryptofinance would be in accordance to their values $(41 \%)$. This could be justified by the fact that traditional banking is commonly used in Mauritius and only those who are well-versed with Blockchain would use this technology.

\section{Need for Personal Interaction}

Question 9 attempts to assess the extent to which respondents feel the need to interact with bankers. 
Table 30: Need for Personal Interaction

\begin{tabular}{|l|c|c|c|c|c|c|}
\hline \multicolumn{1}{|c|}{ Statements } & $\begin{array}{c}\text { Strongly } \\
\text { Disagree \% }\end{array}$ & $\begin{array}{c}\text { Disagree } \\
\%\end{array}$ & $\begin{array}{c}\text { Neutral } \\
\%\end{array}$ & $\begin{array}{c}\text { Agree } \\
\%\end{array}$ & $\begin{array}{c}\text { StronglyAgree } \\
\%\end{array}$ & $\begin{array}{c}\text { Total } \\
\%\end{array}$ \\
\hline $\begin{array}{l}\text { My preference for face-to-face } \\
\text { interaction rather than using } \\
\text { mobile devices or computers. }\end{array}$ & & & & & & \\
\hline $\begin{array}{l}\text { To seek proper guidance in case } \\
\text { of queries. }\end{array}$ & 3 & 30 & 23 & 34 & 8 & 100 \\
\hline
\end{tabular}

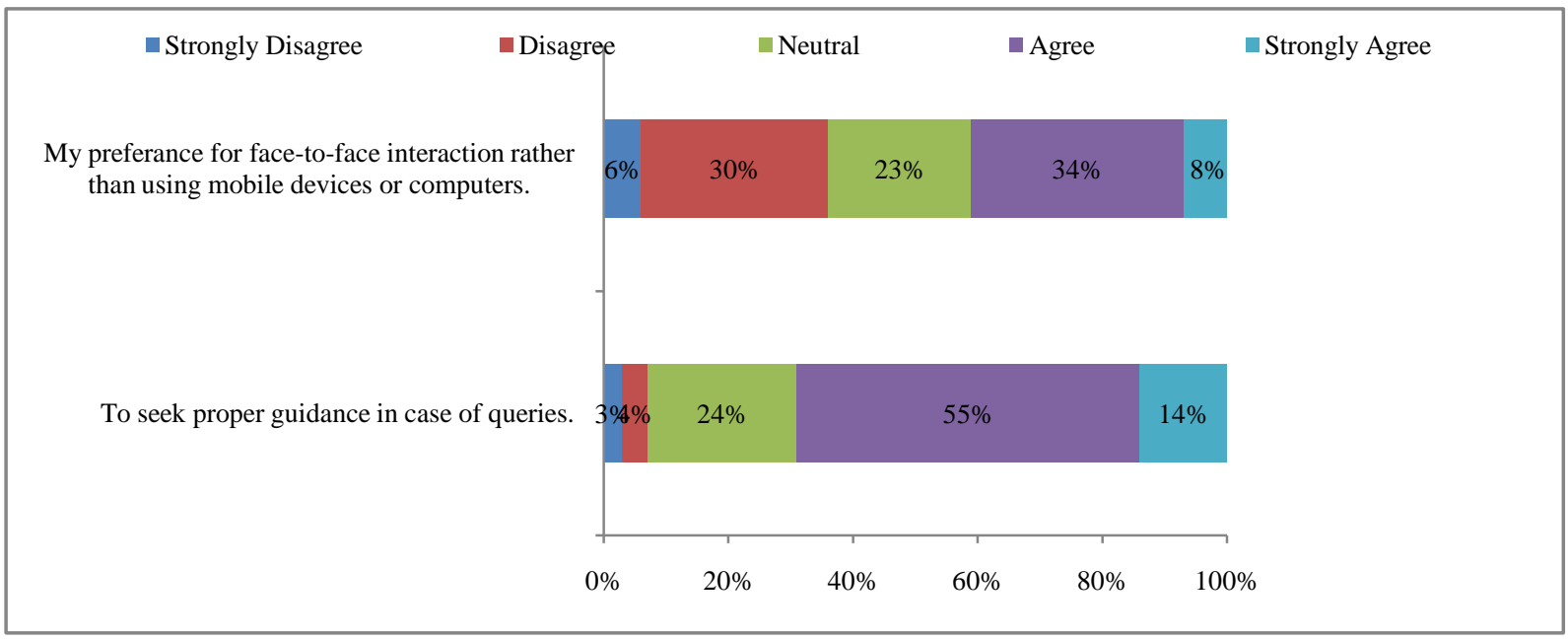

Figure 14: Need for personal interaction

It can be observed from the chart above that $30 \%$ of the respondents disagreed to the fact that they preferred face-to-face interaction rather than using mobile devices or computers. Being in the technological era, many individuals prefer easy access to their banking details and perform their transactions rather than queuing for long hours in the bank. Nevertheless, $34 \%$ of the respondents agreed that they still require the face-to-face interaction rather than mobile phones or computers. This is normally the case for the Mauritian customers who have their personal representatives at the bank, and they can easily discuss about wealth management. It has been proven that as the salary of an individual increases, their savings might increase as well as their investment in financial products. As such, the need for a face-to-face interaction can be deemed as important.

It can be depicted from the above chart that more than half of the respondents agree that they could seek proper guidance in case of queries (55\%). It is indeed the case for some investments at the bank, the guidance of the bankers is crucial for the decision-making process. The number of branches operating in Mauritius are the evidence that customers still need guidance for queries and often seek assistance for major transactions.

\section{Perceived Trust}

Question 10 attempts to measure the degree of trust customers had while using cryptocurrency. 


\section{Table 11: Perceived Trust}

\begin{tabular}{|c|c|c|c|c|c|c|}
\hline Statements & $\begin{array}{c}\text { StronglyDisagree } \\
\%\end{array}$ & $\begin{array}{c}\text { Disagree } \\
\%\end{array}$ & $\begin{array}{c}\text { Neutral } \\
\%\end{array}$ & $\begin{array}{c}\text { Agree } \\
\%\end{array}$ & $\begin{array}{c}\text { StronglyAgree } \\
\%\end{array}$ & $\begin{array}{c}\text { Total } \\
\%\end{array}$ \\
\hline I trust the use of cryptocurrency. & 6 & 18 & 37 & 37 & 3 & 100 \\
\hline The software, Blockchain is trustworthy & 3 & 17 & 34 & 39 & 7 & 100 \\
\hline The users can be trusted & 4 & 23 & 51 & 23 & 0 & 100 \\
\hline
\end{tabular}

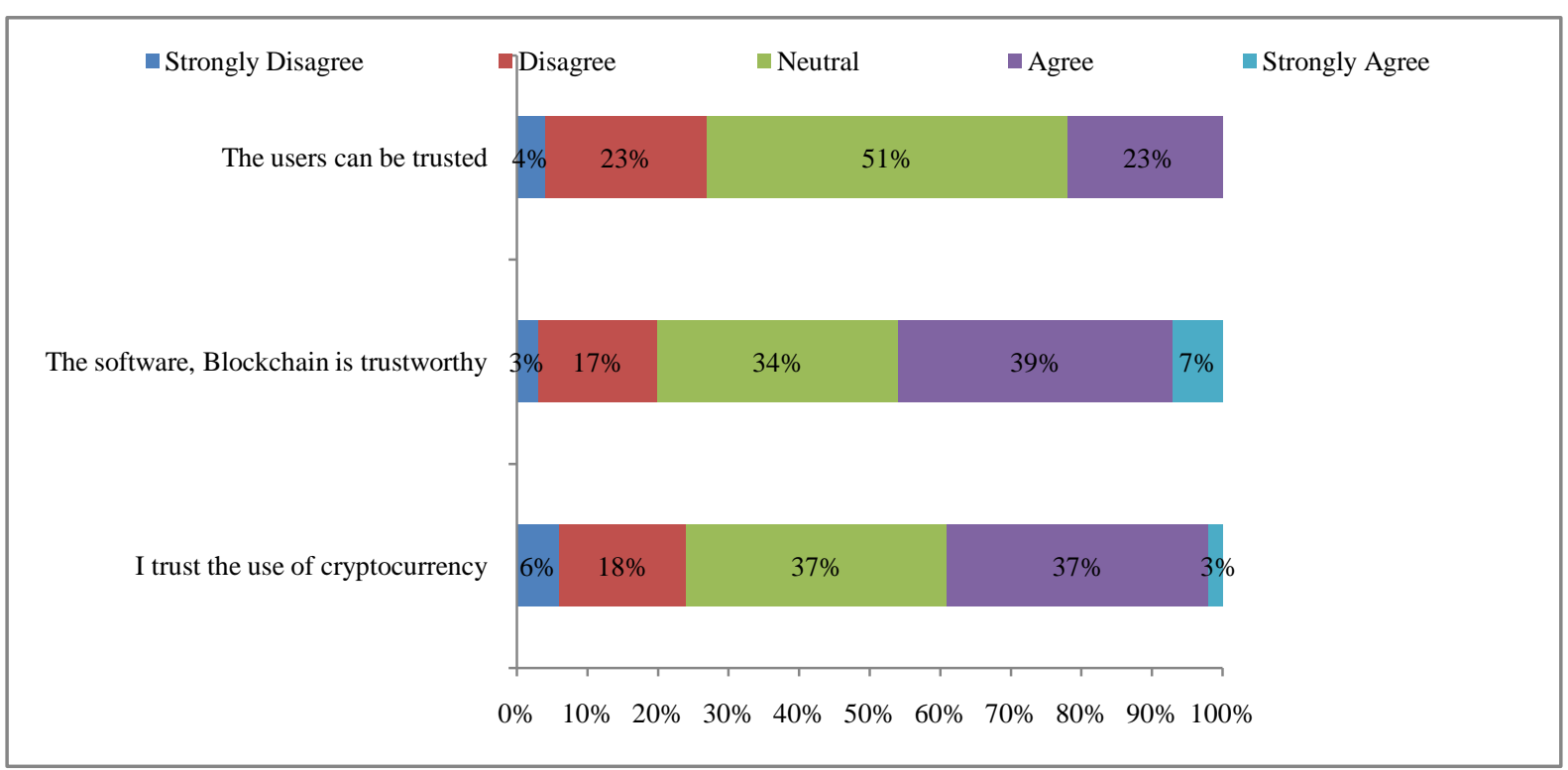

\section{Figure 15: Perceived Trust}

It has been noted from the chart and table above that $37 \%$ of the respondents agreed that they trust the use of cryptocurrency and the same number of respondents $(37 \%)$ voted neither agree nor disagree regarding the trust for using cryptocurrency. The Bank of Mauritius, the central Bank in Mauritius, has issued a communique against the use of cryptocurrency. This communique was published in August 2017. It stated that the Bank of Mauritius does not guarantee the issue of cryptocurrencies and the users are exposed to risks. It was advised to the public in general that the platforms for the exchange of cryptocurrencies are not regulated. It was clearly stipulated that exchange of the cryptocurrencies could entail losses. This could explain why some of the respondents were indecisive about the use of cryptocurrency.

$39 \%$ of the respondents agreed that the software, Blockchain is trustworthy. With the evolution in technology, emphasis is also being laid on the security aspect. For customers to invest in cryptocurrency, they should in the first instance feel comfortable that their investments are safe and secured. Blockchain is highly complex to be decoded. The probability that Blockchain could fail is low but not impossible. Some respondents neither agreed nor disagreed to this section $(34 \%)$.

$51 \%$ of the participants neither agreed nor disagreed that the users could be trusted. This figure could be explained with the reasoning that there are some compliance issues involved with the exchange of 
cryptocurrencies. There might also be financial losses and the losses could be substantial. For the risk-averse customers, they would prefer traditional banking.

\section{Hypothesis 1:}

\section{Results}

$\mathrm{H}_{\mathrm{o}}$ : The age group of the participants has no influence on the perceived risks to use cryptocurrency (Questions 15 and 7 (b))

$\mathrm{H}_{1}$ : The age group of the participants has an influence on the perceived risks to use cryptocurrency (Questions 15 and 7 (b))

Tablecomparing "age group of participants" and "it is not secure: I can be faced with financial loss and compliance issues".

Table 12: Hypothesis 1

\begin{tabular}{|c|c|c|c|c|c|c|c|}
\hline & & \multicolumn{5}{|c|}{ It is not secure: I can be faced with financial loss and compliance issues. } & \multirow[b]{2}{*}{ Total $(\%)$} \\
\hline & & $\begin{array}{c}\text { StronglyDisagree } \\
(\%)\end{array}$ & Disagree (\%) & $\begin{array}{c}\text { Neutral } \\
(\%)\end{array}$ & Agree (\%) & $\begin{array}{c}\text { StronglyAgree } \\
(\%)\end{array}$ & \\
\hline \multirow{6}{*}{$\begin{array}{c}\text { Age } \\
\text { Group }\end{array}$} & 18 - 24 years & 3 & 11 & 8 & 11 & 7 & 41 \\
\hline & 25 - 34 years & 1 & 4 & 8 & 17 & 0 & 31 \\
\hline & 35 - 44 years & 0 & 6 & 7 & 7 & 0 & 20 \\
\hline & 45 - 54 years & 0 & 3 & 0 & 0 & 3 & 6 \\
\hline & $\begin{array}{l}55 \text { years and } \\
\text { above }\end{array}$ & 1 & 0 & 0 & 1 & 0 & 3 \\
\hline & Total (\%) & 6 & 24 & 24 & 37 & 10 & 100 \\
\hline
\end{tabular}

The above table gives an indication that $41 \%$ of the respondents feel insecure with regards to the use of cryptocurrency as they might be faced with financial loss and compliance issues. The highest response rate has been recorded among the age group of 18-24 years (41\%) followed by 31\% among the age group of 25-34 years.

Table 13: Chi-Square Test-Age and Perceived Risk

\begin{tabular}{|l|r|r|r|}
\hline & \multicolumn{1}{|c|}{ Chilue } & \multicolumn{1}{|c|}{$\mathrm{df}$} & $\begin{array}{c}\text { Asymp. Sig. (2- } \\
\text { sided) }\end{array}$ \\
\hline Pearson Chi-Square & $26.110^{\mathrm{a}}$ & 16 & .052 \\
Likelihood Ratio & 26.256 & 16 & .051 \\
Linear-by-Linear Association & .269 & 1 & .604 \\
N of Valid Cases & 71 & & \\
\hline
\end{tabular}

19 cells $(76.0 \%)$ have expected count less than 5. The minimum expected count is .11. 
It can be seen from the statistics that $\mathbf{p = 0 . 0 5 2}$ which is more than $\mathbf{p = 0 . 0 5}, \mathrm{H}_{\mathrm{o}}$ is accepted. Since $\mathrm{H}_{\mathrm{o}}$ is accepted, it implies that the age group of the participants has no influence on the perceived risks to use cryptocurrency.

The calculation of the Spearman's rho demonstrated a significant correlation of p-value of 0.599. It further confirms that there is no association between the age group of the participants and perceived risks to use cryptocurrency.

\section{Hypothesis 2:}

$\mathrm{H}_{\mathrm{o}}$ : The perceived trust to use cryptocurrency is not influenced by the gender of respondents (Questions 10 (a) and 14)

$\mathrm{H}_{1}$ : The perceived trust to use cryptocurrency is influenced by the gender of the respondents (Questions 10 (a) and 14)

Tablecomparing "I trust the use of cryptocurrency" and "gender of respondents"

Table 44: Hypothesis 2

\begin{tabular}{|c|c|c|c|c|c|c|c|}
\hline & & \multicolumn{5}{|c|}{ I trust the use of cryptocurrency. } & \multirow[b]{2}{*}{$\begin{array}{r}\text { Tota } \\
(\%)\end{array}$} \\
\hline & & $\begin{array}{c}\text { StronglyDisagree } \\
(\%)\end{array}$ & $\begin{array}{c}\text { Disagree } \\
(\%)\end{array}$ & $\begin{array}{c}\text { Neutral } \\
(\%)\end{array}$ & Agree (\%) & $\begin{array}{c}\text { StronglyAgree } \\
(\%)\end{array}$ & \\
\hline \multirow{3}{*}{ Gender } & Male & 1 & 6 & 4 & 10 & 1 & 23 \\
\hline & Female & 3 & 13 & 37 & 23 & 3 & 77 \\
\hline & Total (\%) & 4 & 18 & 41 & 32 & 4 & 100 \\
\hline
\end{tabular}

It can be observed from the above table that $77 \%$ of the respondents are female counterparts while only $23 \%$ represent the male ones. Out of the $77 \%$ response rate, $37 \%$ neither agreed nor disagreed that they trust the use of cryptocurrency. Nevertheless, $23 \%$ agreed that they trust the use of cryptocurrency.

The Chi-Square Test and the Spearman's rho were used to test the relationship of the two variables as per the table below.

Table 15: Chi-Square Test - Perceived Trust to use Cryptocurrency and Gender

\section{Chi-Square Tests}

\begin{tabular}{|c|c|c|c|}
\hline & Value & $\mathrm{df}$ & $\begin{array}{l}\text { Asymp. Sig. (2- } \\
\text { sided) }\end{array}$ \\
\hline Pearson Chi-Square & $12.124^{\mathrm{a}}$ & 4 & .016 \\
\hline Likelihood Ratio & 10.490 & 4 & .033 \\
\hline Linear-by-Linear Association & 4.778 & 1 & .029 \\
\hline $\mathrm{N}$ of Valid Cases & 71 & & \\
\hline
\end{tabular}

5 cells $(50.0 \%)$ have expected count less than 5 . The minimum expected count is .90 . 
The calculation of the Chi-Square test gives a p-value of $\mathbf{0 . 0 1 6}$ which is less than $5 \%$. It implies $\mathrm{H}_{\mathrm{o}}$ is rejected. It has been confirmed through the test that gender of the respondents influences the perceived trust to use cryptocurrency.

Statistics from official census conducted that the Mauritian population composed of more female inhabitants than male ones. This can explain the response rate being high and perceived trust being influenced by gender of participants.

The Spearman's rho generated a p-value of $\mathbf{0 . 0 1 7}$ which is less than 0.05 . This also confirms that there is an association between the gender of the respondents and the perceived trust to use cryptocurrency.

\section{Hypothesis 3:}

$\mathrm{H}_{\mathrm{o}}$ : The perceived usefulness of cryptocurrency does not depend on the level of education (Questions 5 (a) and 16)

$\mathrm{H}_{1}$ : The perceived usefulness of cryptocurrency depends on the level of education (Questions 5 (a) and 16)

Cross Tabulation between the "respondents' level of education" and "perceived usefulness of cryptocurrency"

Table 16: Hypothesis 3

\begin{tabular}{|c|c|c|c|c|c|c|c|}
\hline & & \multicolumn{5}{|c|}{ Cryptocurrency is simple and convenient to use. } & \multirow[b]{2}{*}{$\begin{array}{c}\text { Total } \\
(\%)\end{array}$} \\
\hline & & $\begin{array}{c}\text { StronglyDisagree } \\
(\%)\end{array}$ & $\begin{array}{c}\text { Disagree } \\
(\%)\end{array}$ & Neutral (\%) & $\begin{array}{c}\text { Agree } \\
(\%)\end{array}$ & $\begin{array}{c}\text { StronglyAgree } \\
(\%)\end{array}$ & \\
\hline \multirow{6}{*}{$\begin{array}{l}\text { Level of } \\
\text { Education }\end{array}$} & Secondary & $\mathbf{0}$ & $\mathbf{0}$ & 6 & 6 & 4 & 15 \\
\hline & Diploma & $\mathbf{0}$ & $\mathbf{0}$ & 3 & 3 & 1 & 7 \\
\hline & Undergraduate & 1 & $\mathbf{0}$ & 6 & 38 & 15 & 61 \\
\hline & Postgraduate & 1 & $\mathbf{0}$ & 3 & 8 & 3 & 15 \\
\hline & Others & $\mathbf{0}$ & 1 & $\mathbf{0}$ & $\mathbf{0}$ & $\mathbf{0}$ & 1 \\
\hline & Total & 3 & 1 & 17 & 55 & 24 & 100 \\
\hline
\end{tabular}

From the table above, the response rate of $61 \%$ represented the undergraduate degree holders and $15 \%$ represented postgraduate degree holders. Out of the $61 \%, 38 \%$ agreed that cryptocurrency is convenient and easy to use. Based on a study conducted by the Mauritian Statistics Bureau, many citizens are degree holders nowadays. The reason behind high number so Mauritians being degree holders is the accessibility to pay the university fees. 
Table 17: Chi-Square Test-Perceived Usefulness of Cryptocurrency and Level of Education of respondents

Chi-Square Tests

\begin{tabular}{|l|r|r|r|}
\hline & \multicolumn{1}{|c|}{ Value } & df & \multicolumn{1}{|c|}{$\begin{array}{c}\text { Asymp. Sig. (2- } \\
\text { sided) }\end{array}$} \\
\hline Pearson Chi-Square & $82.272^{\mathrm{a}}$ & 16 & .000 \\
Likelihood Ratio & 20.722 & 16 & .189 \\
Linear-by-Linear Association & .899 & 1 & .343 \\
N of Valid Cases & 71 & & \\
\hline
\end{tabular}

20 cells $(80.0 \%)$ have expected count less than 5 . The minimum expected count is .01 .

The Chi-Square test provides p-value of $\mathbf{0 . 0 0 0}$ which is less than 0.05 , therefore $\mathbf{H}_{\mathbf{0}}$ is rejected. The Spearman's rho confirms the calculation, providing a value of $\mathbf{0 . 0 0 0}$ as well. It can be deduced that the perceived usefulness of cryptocurrency depends on the level of education.

This is a reality in most countries worldwide and Mauritius is not an exception. As the level of education of the respondents is higher, the more likely the customers will make use of technological advances. The undergraduates form part of the working population and will prefer to use cryptocurrency. Time factor encourages the use of cryptocurrency.

\section{Hypothesis 4:}

$\mathrm{H}_{\mathrm{o}}$ : The perceived cost for the use of cryptocurrency does not depend on the monthly income of the respondents (Questions 7(d) and 18)

$\mathrm{H}_{1}$ : The perceived cost for the use of cryptocurrency depends on the monthly income of the respondents (Questions 7(d) and 18)

Tablecomparing"perceived cost for the use of cryptocurrency" and "monthly income"

\section{Table 18: Hypothesis 4}

\begin{tabular}{|c|c|c|c|c|c|c|c|}
\hline & & \multicolumn{5}{|c|}{ Transaction fees to use cryptocurrency are low. } & \multirow[b]{2}{*}{$\begin{array}{l}\text { Total } \\
\text { (\%) }\end{array}$} \\
\hline & & $\begin{array}{c}\text { StronglyDisagree } \\
(\%)\end{array}$ & Disagree (\%) & $\begin{array}{c}\text { Neutral } \\
(\%)\end{array}$ & $\begin{array}{c}\text { Agree } \\
(\%)\end{array}$ & $\begin{array}{c}\text { StronglyAgree } \\
(\%)\end{array}$ & \\
\hline \multirow{7}{*}{ MonthlyIncome } & $\begin{array}{l}\text { Under } \\
10,000\end{array}$ & 0 & 4 & 7 & 0 & 3 & 14 \\
\hline & $\begin{array}{l}\text { Rs 10,001- } \\
\text { Rs 20,000 }\end{array}$ & 3 & 6 & 7 & 3 & 1 & 20 \\
\hline & $\begin{array}{l}\text { Rs 20,001- } \\
\text { Rs 30,000 }\end{array}$ & 0 & 4 & 13 & 0 & 0 & 17 \\
\hline & $\begin{array}{l}\text { Rs } \quad 30,001- \\
\text { Rs } 40,000\end{array}$ & 0 & 0 & 0 & 1 & 0 & 1 \\
\hline & $\begin{array}{l}\text { AboveRs } \\
40,001\end{array}$ & 0 & 7 & 7 & 1 & 1 & 17 \\
\hline & None & 3 & 8 & 14 & 6 & 0 & 31 \\
\hline & Total & 3 & 30 & 48 & 11 & 6 & 100 \\
\hline
\end{tabular}


The table above shows the respondents with no monthly income (termed as 'none' $31 \%$ ) have agreed that the transaction fees to use cryptocurrency are low. These respondents are mainly the students pursuing their studies who participated to the survey.

Table 19: Chi-Square Test-Perceived cost for the use of cryptocurrency and Monthly income

\begin{tabular}{|l|r|r|r|}
\hline & \multicolumn{1}{|c|}{ Chi-Square Tests } & df & $\begin{array}{c}\text { Asymp. Sig. (2- } \\
\text { sided) }\end{array}$ \\
\hline Pearson Chi-Square & $33.071^{\mathrm{a}}$ & 25 & .129 \\
Likelihood Ratio & 31.534 & 25 & .172 \\
Linear-by-Linear Association & .644 & 1 & .422 \\
N of Valid Cases & 71 & & \\
\hline
\end{tabular}

32 cells $(88.9 \%)$ have expected count less than 5 . The minimum expected count is .01.

The Chi-Square Test has a p-value of 0.129 which is greater than 0.05 . Hence, $\mathrm{H}_{\mathrm{o}}$ is accepted. It can therefore be concluded that the perceived cost for the use of cryptocurrency does not depend on the monthly income of the respondents. The Spearman's rho confirms the results of the Chi-Square test where $p=0.957$. This implies that the monthly income of the respondents does not affect the perceived cost for the use of cryptocurrency.

\section{Hypothesis 5:}

$\mathrm{H}_{\mathrm{o}}$ : There exists no relationship between the occupation of the respondents and compatibility with needs and lifestyle (Questions 17 and 8(b))

$\mathrm{H}_{1}$ : There exists a relationship between the occupation of the respondents and compatibility with needs and lifestyle (Questions 17 and 8(b))

Table comparing "compatibility with lifestyle and needs" and "current occupation"

Table 20: Hypothesis 5

\begin{tabular}{|c|c|c|c|c|c|c|c|}
\hline & & \multicolumn{5}{|c|}{ Use of blockchain suits my lifestyle. } & \multirow[b]{2}{*}{$\begin{array}{r}\text { Total } \\
(\%)\end{array}$} \\
\hline & & $\begin{array}{c}\text { StronglyDisagree } \\
(\%)\end{array}$ & $\begin{array}{c}\text { Disagree } \\
(\%)\end{array}$ & $\begin{array}{c}\text { Neutral } \\
(\%)\end{array}$ & $\begin{array}{c}\text { Agree } \\
(\%)\end{array}$ & $\begin{array}{c}\text { StronglyAgree } \\
(\%)\end{array}$ & \\
\hline \multirow{6}{*}{$\begin{array}{c}\text { Current } \\
\text { Occupation }\end{array}$} & Student & 1 & 6 & 11 & 14 & 4 & 37 \\
\hline & Employed & 1 & 6 & 14 & 34 & 6 & 61 \\
\hline & Unemployed & 0 & 0 & 0 & 3 & 0 & 3 \\
\hline & Retired & 0 & 0 & 0 & 0 & 0 & 0 \\
\hline & Other & 0 & 0 & 0 & 0 & 0 & 0 \\
\hline & Total & 3 & 11 & 25 & 51 & 10 & 100 \\
\hline
\end{tabular}

Based on the above table, $34 \%$ out of $61 \%$ employed respondents have agreed that the use of cryptofinance suits their lifestyle. Millennials are of the opinion that they should make the most of technological advances in view to ease their lives and benefit from their spare time. Even the students feel that the use of cryptofinance suits their lifestyle. 
Table 5: Chi-Square Test - Current Occupation and Compatibility with lifestyle and needs

\begin{tabular}{|l|r|r|r|}
\hline & \multicolumn{1}{|c|}{ Chi-Square Tests } & \multicolumn{1}{c|}{ df } & $\begin{array}{c}\text { Asymp. Sig. (2- } \\
\text { sided) }\end{array}$ \\
\hline Pearson Chi-Square & $5.010^{\mathrm{a}}$ & 10 & .891 \\
Likelihood Ratio & 6.090 & 10 & .808 \\
Linear-by-Linear Association & 1.487 & 1 & .223 \\
N of Valid Cases & 71 & & \\
\hline
\end{tabular}

14 cells $(77.8 \%)$ have expected count less than 5 . The minimum expected count is .03 .

The Chi-Square Test performed generates a p-value of $\mathbf{0 . 8 9 1}$ which is greater than 0.05 . This means that $\mathrm{H}_{\mathrm{o}}$ is accepted. The findings affirmed that there exists no relationship between the occupation of the respondents and compatibility with needs and lifestyle.

As for the Spearman's rho, the p-value is $\mathbf{0 . 2 2 8}$ which also matches the results from the Chi-Square Test. It can be concluded that there is no association with the occupation of the respondents and the compatibility with the needs and lifestyle. The use of cryptofinance does not rely on the occupation of the participants to the survey.

\section{Recommandations and Conclusion}

Cryptofinance will take time to evolve as per the findings and analysis conducted. It has been observed through the study that cryptofinance is not adopted to a large scale, and that traditional banking is being preferred by the customers. The study targeted users and non-users from the different categories of the population. The categories included the students, employees, the unemployed and even retired persons. It can be depicted from the findings that many are aware of cryptofinance but only to some extent. Concerning the sample for the analysis, it has been found that there were more female respondents as compared to the male ones as per of the data collected process. It should not be concluded that cryptofinance would have a future in Mauritius.

\section{Recommendations}

Our recommendations span three main issues: security, regulated framework and tracking system

\section{Security}

With regards to security, it has been proven that if the users of cryptofinance lack trust, the less likely they would use cryptofinance. Reality bears evidence in cases where customers have suffered from financial losses for the use of cryptofinance. An adequate system should be put in place so that in case of failure of the system, a back-up is available for the investment in cryptofinance to be on-going.

\section{Regulated Framework}

It is to be highlighted that cryptofinance is not regulated by any financial institution in Mauritius for the time being. If the Bank of Mauritius had issued a special licence to the companies dealing with cryptocurrency, there could be a gradual increase in the use of cryptofinance. Since cryptofinance is not properly regulated, many Mauritians still prefer to use the traditional banking system. In case the Bank of Mauritius would issue special regulations and restrictions on the use of cryptocurrency, there could be users who would feel more secured to use it. Very often, when parameters are set within a financial landscape for a financial product or service, even the risk averse customers could invest to some extent. Regulations should be put in place to govern the compliance issues and set the price of the cryptocurrency. 
Tracking system

A tracking system as in any other service provided to customers must be properly defined. It is recommended to have such a system to monitor the transactions happening per second on the exchange platform. A tracking system can be used to avoid loss of data and dealing of illicit activities. The authorities should have a superior hand in the monitoring of financial transactions in view to avoid a possible crash of the economy.

\section{Limitation and Scope for further research}

100 respondents were interviewed for the survey. As such, the results should not be assumed as a full reflection of the Mauritian population.

The respondents were mainly university students and employees in the financial sector. Further research could be conducted from employees of other sectors of the economy. The larger the sample size, the better for analysis of the data.

\section{Conclusion}

It can therefore be concluded following the study that cryptocurrency can have a future in Mauritius, provided the authorities put in place the regulations. Fintech is evolving in the emerging markets. Moving to a new dimension in the technological era entails the question of what would happen in case of the shift towards blockchain. It seems unrealistic to think that blockchain will bring changes to the financial ecosystem. Customer service relationship will still impact on the way of doing business along with the brand and reputation of the banks. Banks are obliged to meet the regulatory requirements at a national and international level. Banks if not scrutinized properly could lead to a crisis in the economy. This would have a domino-effect on the economy and the related stakeholders might face with substantial losses. There could be reputational, legal and credit risks involved. The shift towards the adoption of cryptocurrency is a gradual process. It can take several years for Mauritius to allow customers to use of cryptocurrency.

References
[1] BBVA Innovation Center. Blockchain Technology. London: BBVA Innovation Center, 2017.

[2] Bhattacherjee A. "Individual trust in online firms: Scale development and initial test." Journal of Management Information Systems, 19(1), 2002: 211-241.

[3] Cabaleiro, Roerto, Enrique Buch, and Antonio Vaamonde. "Developing a Method to Assessing the Municipal Financial Health." The American Review of Public Administration 43, no. 6 (2013): 729-751.

[4] Carr, Jered B., and Shanthi Karuppusamy. "Reassessing the Link between City Structure and Fiscal Policy." The American Review of Public Administration 40, no. 2 (2010): 209-228.

[5] Catalini C. and Gans Joshua S. "Some Simple Economics of the Blockchain." SSRN, 2017.

[6] Chohan, Usman W. "Cryptocurrencies: A Brief Thematic Review." SSRN, 2017: 1-9.

[7] Choi, Jong-Hag, Chansog Kim, Jeong-Bon Kim, and Yoonseok Zang. "Audit Office Size, Audit Quality and Audit Pricing." Auditing : A Journal of Practice and Theory 29, no. 1 (2010): 73-97.

[8] Chowdry B. Bitcoin, Freedom, and the Future of Finance? (December 28, 2015).

[9] Cohen, Sandra, Michael Doumpos, Evi Neofytou, and Costantin Zopoundis. "Assessing Financial Distress where Bankruptcy is not an Option : An alternative Approach for Local Municipalities." European Journal of Operational Research 218, no. 1 (2012): $270-279$.

[10] Curran James M. and Meuter Matthew L. "Self-service technology adoption: comparing three technologies." Journal of Services Marketing 19, no. 2 (2005): 103-113.

[11] Dabholkar Pratibha A. "Consumer evaluations of new technology-based self-service options: An investigation of alternative models of service quality." International Journal of Research in Marketing 13, no. 1 (1996): 29-51.

[12] Das T. K. and Teng Bing-S. "Trust, Control, and Risk in Strategic Alliances: An Integrated Framework." Electronic Law Journal, 2001: 253-258. 
[13] Erdem T. and Swait J. "Brand Credibility, Brand Consideration, and Choice." Journal of Consumer Research 31, no. 1 (2004): 191198.

[14] Farell R. "An Analysis of the Cryptocurrency Industry." 2015.

[15] Feng X., Fu S., and Qin F. "Determinants of consumers' attitudes toward mobile advertising: The mediating roles of intrinsic and extrinsic motivations." 63 (2016): 334-341.

[16] Finextra Research Ltd. "Banking on Blockchain: Charting the progress of Distributed Ledger Technology in Financial Services." 2016.

[17] Forsthe S. "Consumer Patronage and Risk Perceptions in Internet Shopping." Journal of Business Research 56, no. 11 (2003): 867875.

[18] Gao, Pengjie, Change Lee, and Dermot Murphy. "Municipal Borrowing Costs and State Policies for distressed Municipalities." Journal of Financial Economics (https://doi.org/10.1016/j.jfineco.2018.10.009), 2018: https://doi.org/10.1016/j.jfineco.2018.10.009

[19] Gefen D., Karahanna E. and Straub Detmar W. . "Trust and TAM in Online Shopping: An Integrated Model." 27, no. 1 (2003): $51-90$.

[20] Guillamon, M., B. Benito, and F. Bastida. "Evaluation of local government debt in Spain." Revista Espanola de Financiacion y Contabilidad 40, no. 150 (2011): 251-285.

[21] Harvey Campbell R. "Cryptofinance." SSRN, 2016: 2-7.

[22] Hourahine B., Howard M. "Money on the move: Opportunities for financial service providers in the "third space'." Journal of Financial Services Marketing 9, no. 1 (2004): 57-67.

[23] Karaa, Imen, and Noureddine Benlagha. "Testing for Asymmetric Information in Tunisian Automobile Insurance market." Mediterranean Journal of Social Sciences 6, no. 3 (2015): 455-465.

[24] Karaa, Noureddine Benlagha and Imen. "Evidence of Adverse Selection in Automobil Insurance Market : A Seemingly Unrelated Probit Modelling." Cogent Economics and Finance 5 (2017): 133-149.

[25] Khayati S. "Perceived Usefulness and Use of Information Technology: the Moderating Influences of the Dependence of a Subcontractor towards His Contractor." Scientific Papers III (2013): 1-3.

[26] Kooli K., Mansour Kaouther B., Utama R. "Determinants of online trust and their impact on online purchase intention." International Journal of Technology Marketing 9, no. 3 (2014): 305-319.

[27] Lee Hyun-H., Fiore A. \& Kim J. . "The role of the Technology Acceptance Model in explaining effects of image interactivity technology on consumer responses." International Journal of Retail \& Distribution Management 34 (2006): 621-644.

[28] Naicken L. "Effect of Internet Banking and Mobile Banking on the tertiary and secondary working population of Mauritius." Mauritius: University of Mauritius Press, 2012.

[29] Navarro-Galera, Andrès, Juan Lara-Rubio, Dionisio Buendia-Carrillo, and Salvador Rayo-Canton. "What can increase the Default Risk in Local Governments ?" International Review of Administrative Sciences 83, no. 2 (Juin 2017): 397-419.

[30] PwC. Pwc Global Fintech Report. United Kingdom: PwC, 2017.

[31] Scott, Daniel. A Model for the Determination of the Creditworthiness of Municipalities in South Africa. Pretoria: University of South Africa, 2001.

[32] Syndicated News SNN.BZ. Deloitte Blockchain Enigma. Paradox. Opportunity. 2016.

[33] Taylor James W. "The Role of Risk in Consumer Behavior." Journal of Marketing 38, no. 2 (1974).

[34] Wessels L. and Drennan J. "An investigation of customer acceptance of m-banking." International Journal of bank marketing, 2010: 547-568. 